\title{
Zooplankton associated with phytotelms and treefrogs in a neotropical forest
}

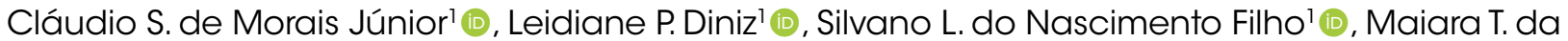

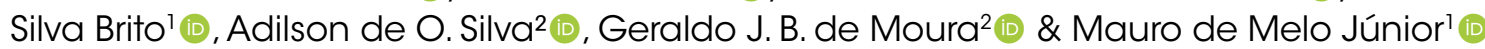

\author{
1. Universidade Federal Rural de Pernambuco, Departamento de Biologia, Laboratório de Ecologia do Plâncton (UFRPE/LEPLANC). Rua Dom Manoel de Medeiros, s/n, \\ Dois Irmãos, 52171-900, Recife, Pernambuco, Brazil. (maiaratabatha@hotmail.com) \\ 2. Universidade Federal Rural de Pernambuco, Departamento de Biologia, Laboratório de Herpetologia e Paleontologia (UFRPE/LEHP).
}

Received 23 March 2018

Accepted 29 April 2019

Published 30 May 2019

DOI 10.1590/1678-4766e2019020

\begin{abstract}
Assumptions about the distribution of zooplankton communities in various ecosystems are often limited by lack of data on dispersal mechanisms. Many studies on frog-mediated passive dispersal have been developed in bromeliads, but they usually focus on ostracods and annelids. We investigated the potential for external phoresy of zooplankton (rotifers, cladocerans, copepods) by treefrogs in bromeliad phytotelms. Our hypotheses are that (1) zooplankton composition on frogs' skin and in phytotelm tanks is similar, and (2) frogs with larger body size carry more propagules of these invertebrates. We filtered phytotelm water (10 to $150 \mathrm{~mL})$ using plankton net $(45 \mu \mathrm{m})$, and fixed invertebrates with $4 \%$ formalin. Frogs were actively collected in and around bromeliads (up to $\sim 1.5 \mathrm{~m}$ radius) and then washed with distilled water. Fourteen species of rotifers and three of crustaceans were registered in phytotelm water and frog bodies. We captured 17 frogs with a snout-vent length (SVL) ranging from 2 to 5 cm and belonging to five species: Pristimantis ramagii (Boulenger, 1888), Dendropsophus decipiens (A. Lutz, 1925), Scinax auratus (Wied-Neuwied,1821), S. pachycrus (Miranda-Ribeiro, 1937) and S. x-signatus (Spix, 1824). Among them, $12(70.59 \%)$ had propagules adhered to their bodies, of which the majority (ten individuals) had active zooplankton forms, while only two had dormant eggs. Ten rotifer and two microcrustacean species were recorded adhered to frogs. The zooplankton composition differed between phytotelms and anuran skin, and frog body size does not explain the number of propagules carried, refuting both hypotheses. However, evidence of dispersal was found due to the high number of propagules adhered to anurans. Our study provides evidence that frogs may be potential dispersers of dormant and active forms of zooplankton in bromeliads, through external phoresy.
\end{abstract}

KEYWORDS. Frog skin, Atlantic forest, bromeliad, dispersal, epizoochory.

RESUMO. Zooplâncton associado a fitotelmos e anuros arbóreos em uma florestal neotropical. Hipóteses sobre a distribuição das comunidades de zooplâncton em vários ecossistemas são muitas vezes limitadas pela falta de dados sobre os seus mecanismos de dispersão. Muitas pesquisas sobre a dispersão passiva mediada por anuros têm sido desenvolvidas em bromélias, porém com foco em ostrácodes e anelídeos. Nós investigamos o potencial para a forésia externa do zooplâncton (rotíferos, cladóceros, copépodes) por anuros arbóreos em fitotelmos de bromélias. Nossa hipótese é que (1) a composição do zooplâncton presente na pele dos anuros e nos fitotelmos das bromélias é semelhante, e que (2) anuros com maior tamanho corporal carregam mais propágulos de invertebrados. Filtramos a água presente nos fitotelmos (10 a $150 \mathrm{~mL})$ usando uma rede de plâncton (45 $\mu$ m) e fixamos os invertebrados em formol a 4\%. Os anuros foram coletados ativamente em torno das bromélias (até $\sim 1,5 \mathrm{~m}$ de raio) e depois lavados com água destilada. Quatorze espécies de rotíferos e três de crustáceos foram registradas na água dos fitotelmos e no corpo dos anuros. Capturamos 17 anuros variando de 2 a $5 \mathrm{~cm}$ de SLV e pertencentes a cinco espécies: Pristimantis ramagii (Boulenger, 1888), Dendropsophus decipiens (A. Lutz, 1925), Scinax auratus (Wied-Neuwied,1821), S. pachycrus (Miranda-Ribeiro, 1937) e S. x-signatus (Spix, 1824). Entre eles, 12 (70,59\%) tinham propágulos aderidos ao corpo, dos quais a maioria (dez indivíduos) apresentou formas ativas de zooplâncton, enquanto apenas dois apresentaram ovos dormentes. Dez rotíferos e duas espécies de microcrustáceos foram registrados aderidas aos anuros. A composição zooplanctônica diferiu entre os fitotelmos e a pele de anuros e, o tamanho do corpo do dispersor não explicou o número de propágulos transportados, refutando ambas as hipóteses. No entanto, ressaltamos que evidências de dispersão foram encontradas devido ao alto número de propágulos aderidos aos anuros. Nosso estudo fornece evidências de que os anuros podem ser potenciais dispersores de formas ativas e inativas de zooplâncton em bromélias, através de forésia externa.

PALAVRAS-CHAVE. Pele de anuros, Mata Atlântica, bromélia, dispersão, epizoocoria.

Understanding the dispersal mechanisms related to the organization of freshwater zooplankton communities, which can be represented by rotifers, cladocerans and copepods, is essential in increasing knowledge about their distribution and structure in many limnic ecosystems (JENKINS \& UNDERWOOD, 1998; BOHONAK \& JENKINS, 2003). With an increase in dispersal events, the $\beta$-diversity among communities tends to diminish due to the homogenization process of the metacommunity (MOUQUET \& LOREAU, 2003). On the other hand, low dispersal rates may lead to dissimilarity between communities and beta diversity increase (LANGENHEDER \& RAGNARSSON, 2007). In environments located close to each other, dispersal becomes more efficient (COHEN \& SHURIN, 2003) and, therefore, more likely to go towards more similar communities. 
Bromeliads, plants of the Bromeliaceae family, are widely distributed in Brazilian rainforests and are known to have a distinct format, with leaves arranged in rosette form (BENZING, 2000). Many bromeliads have the capacity to store rainwater in a small and sometimes complex microcosm, the phytotelm (BenzING, 2000). Moreover, such "bromeliad tanks" store a supply of nutrients capable of supporting a wide variety of organisms such as zooplankton, macroinvertebrates and a whole food chain of vertebrates, like amphibians, which interact with each other and form a complex food web (NGai \& SRivastava, 2006; Ferreira \& CAVALCANTI, 2010; Islair et al., 2015). Even in bromeliads supporting a high diversity of organisms, changes in water induced by the bromeliads themselves can constitute a barrier for some species (LOPEz et al., 2009). Therefore, the composition of bromeliad species may be quite different from that of aquatic environments located close to it (LiTTLE \& HEBERT, 1996).

As regards amphibians, they can use these microcosms in two different ways: (i) the bromeligenous, which use these plants for their reproductive cycle, and (ii) the bromelicolous, which have no direct relationship with the plant in any aspect of their reproductive cycle, using it only for foraging and shelter (Регхото, 1995). Overall, the bromelicolous frogs have an active character and are constantly moving among bromeliads, seeking mainly refuge or foraging (MAGESKI et al., 2014). This migratory character gives the amphibians the ability to disperse invertebrates that are present in these microcosms (SABAGH \& Rocha, 2014; Lopez et al., 1999, 2005). They can be considered key species to maintain the diversity of aquatic invertebrate communities in those microhabitats (e.g., LOPEZ et al., 1999).

In community ecology, the species richness is a function of environment size; thus, the larger the environment, the more individuals and consequently more species, may be found (HaRveY et al., 1983; UlRich \& Gotelli, 2007). Considering this relationship between area and species richness, the dispersal capacity of amphibians is expected to be greater for larger frog bodies, and therefore more zooplankton propagule species may adhere to them and disperse. In the literature, there is an ecological investigation regarding the portion of the host frog body where bromeliad ostracods commonly adhere (SABAGH \& RoCHA, 2014); however, there is no published evidence, to the best of our knowledge, about the relationship between size and dispersal performance in ostracods or zooplankton. These observations may improve knowledge about zooplankton dispersal and point out the relative importance of those vertebrates.

When referring to rotifers, cladocerans and copepods, we believe this is the first demonstration of phoresy mediated by frogs in bromeliads. Few studies have investigated the relationship between frogs and invertebrates that inhabit the phytotelm of bromeliads (LOPEZ et al., 1999, 2005; SABAGH et al., 2011, 2012; SABAGH \& Rocha, 2014). They emphasize that presence and permanence of these organisms in such plants could be important for frogs, especially regarding disease prevention (BUCK et al., 2011; SCHMELLER et al., 2014).
In this study, we investigated the potential for external phoretic behavior of zooplankton (rotifers, cladocerans, copepods) carried by arboreal frogs between bromeliad phytotelms. As these frogs frequently visit bromeliads for feeding and reproductive purposes, we predict that these vertebrates may be important passive dispersal vectors of zooplankton on a local scale. Our hypotheses are that (i) zooplankton composition on frog's skin and in phytotelm tanks are similar and that (ii) frogs with larger body size carry more propagules of these invertebrates.

\section{MATERIAL AND METHODS}

Study site. The study was conducted in "Refúgio de Vida Silvestre Alto da Buchada" a conservation unit, in a Semideciduous Stationary Forest remnant (Mata do Alto da Buchada and Mata do Camucim), which is characterized by a dry season that lasts two to five months, with similar temperatures all year long (COLOMBo \& JoLY, 2010). It is located in the municipality of São Lourenço da Mata, eastern region of Pernambuco, Brazil $\left(08^{\circ} 04^{\prime} \mathrm{S}\right.$ and $\left.35^{\circ} 12^{\prime} \mathrm{W}\right)$ (Fig. 1).

This Neotropical forest has a total area of approximately 800 ha surrounded by sugarcane monoculture (DUARTE et al., 2007; ANDRADE et al., 2013), of which about 400 ha represent forested areas and 400 ha are covered by the Tapacurá Reservoir, resulting from the damming of the Tapacurá river. The climate is predominantly humid to subhumid, with dry summers and concentration of rainfall between the months of May and September (ALvares et al., 2013).

Collecting procedures. Sampling was carried out in May 2015, during the rainy season, which goes from March to August, according to 30 years historic mean. To access the zooplankton community present in bromeliads, we collected the phytotelm water in 19 randomly chosen bromeliads separated into soil (ten), rupicolous (five) and epiphytical (four) habitats, distributed in an area of $40 \mathrm{~m}^{2}$. Of the 19 bromeliads sampled, ten were from Mata da Buchada (all soil) and nine from Mata do Camucim (five rupiculous and four epiphytical); all of them belonged to the tankbromeliad species Aechmea leptantha (Harms) Leme \& J. A. Siqueira. The bromeliads were only analyzed if they had water stored in at least one tank of their phytotelm. The water volume stored in the bromeliad tanks varied from 10 to $150 \mathrm{~mL}$. The water was collected using a pipette $(5 \mathrm{~mL})$, filtered through plankton net of $45 \mu \mathrm{m}$ mesh size and fixed with $4 \%$ neutral formalin.

To evaluate the potential of bromeliad frogs to disperse zooplankton, we carried out an active search for these animals within the rosettes of bromeliad leaves or in the plant vicinity (radius of $\sim 1.5 \mathrm{~m}$ ), more precisely on soil and on parts of other plants. The frogs found were placed in plastic bags, for later identification, and washed following the method suggested by Lopez et al. (2005). After this procedure, the animals, not sexed, had a morphological measurement verified, the snout-vent length (SVL). The water sample from washing of the individuals was filtered through 


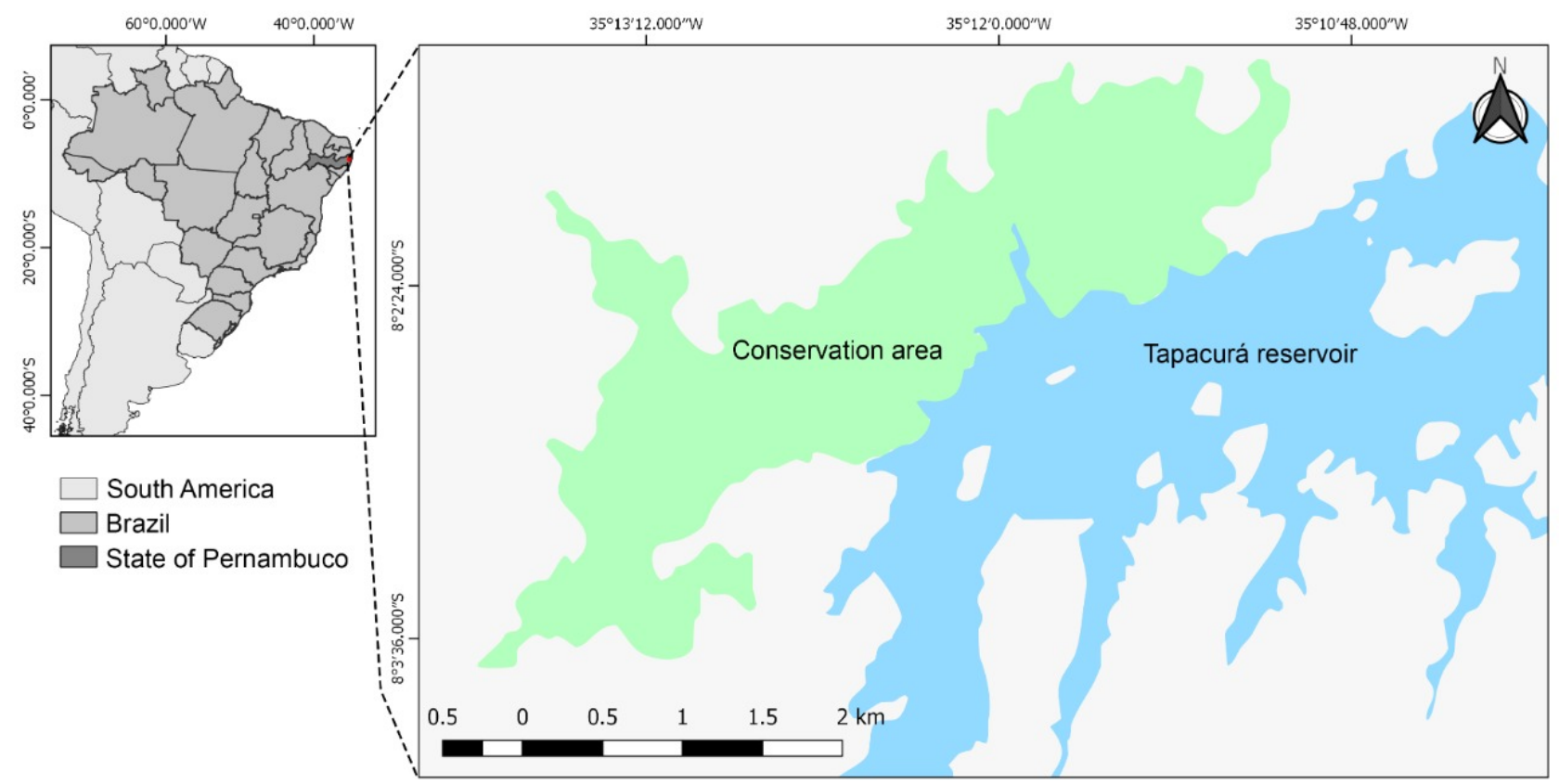

Fig. 1. Location of the conservation unit in the municipality of São Lourenço da Mata, eastern region of Pernambuco, Brazil. In green, the forest was a sample of the study.

plankton net of $45 \mu \mathrm{m}$ mesh and fixed in $4 \%$ formalin. Then the frogs were released into the collection site.

Data analysis. In the laboratory, we examined the zooplankton under an optical microscope and using specialized bibliography (Koste, 1978; ReID, 1985; MatsumuRA-TundisI, 1986; ElMOOR-LOUREIRO, 1997). Their diapause stages and resting eggs were also quantified. We performed the quantification in Sedgwick-Rafter chambers, through a full count of the organisms, both alive and dormant. Data were analyzed for species richness, density (ind.100 $\mathrm{mL}^{-1}$ ) and frequency of occurrence (\%). Rarefaction and extrapolation curves were subsequently generated for propagules from bromeliads and frog's skin, in order to compare their richness. Both curves were based on species frequency and made in the R program using iNEXT package (HsieH et al., 2016).

We performed a Non-Metric Multidimensional Scaling (NMDS) with dissimilarity matrix calculated from the Jaccard method to verify the dissimilarity pattern between the composition on frog's skin and in bromeliads. Next, we tested our hypothesis that zooplankton composition on frog's skin and in phytotelm tanks is similar by multivariate permutation analysis of variance using distance matrices (PERMANOVA, "adonis" function in program R, see OKSANEN et al., 2017). ANDERSON \& WALSH (2013) demonstrated that PERMANOVA is the least sensitive resemblance-permutation method for heterogeneity in dispersions. By combining PERMANOVA with the BETADISPER method, species composition can be compared between groups and within groups (dispersion) (ANDERSON \& WALSH, 2013). In addition, to verify which species contributed to the similarity, the SIMPER analysis (percentage of similarity) was used. This analysis was performed using R program version 3.3.1 (R CORE TEAM, 2018) and Vegan package (OKSANEN et al., 2017).

In order to establish whether the frog's size has some influence on dispersal, the number of individuals found adhered to anuran skin and the snout-vent length (SVL) were submitted to linear regression with SVL as predictive variable and zooplankton propagules as response variable. Normality had been previously tested by the Shapiro-Wilk test.

\section{RESULTS}

The zooplankton community in the bromeliad phytotelm was represented by 17 species, including rotifers, cladocerans, copepods and dormant eggs (Tab. I). Rotifers had the highest richness (12 species). Among the identified rotifers, Lecane closterocerca (Schmarda, 1859) is a new record for the Semideciduous Stationary Forest.

The species richness for zooplankton present in bromeliad phytotelms was higher than that for organisms transported by anurans, and neither rarefaction curve reached the asymptote (Fig. 2). Lecane nana (Murray, 1913), Lepadella patella (Muller, 1773) and the morphotype of the Bdelloidea class were the most frequent rotifers (78.9, 52.6 and $21.1 \%$ respectively). The other species presented less than $16 \%$ of occurrence frequency. The cladoceran and copepod species richness was low (two and three respectively).

The mean of total zooplankton density in bromeliads was 350.4 ind. $100 \mathrm{~mL}^{-1}$ with a standard deviation of 734.2 ind.100 $\mathrm{mL}^{-1}$. The Bdelloidea rotifers $(296.2 \pm 691.5$ ind. $\left.100 \mathrm{~mL}^{-1}\right)$, Lecane closterocerca $\left(19.6 \pm 63.5\right.$ ind. $\left.100 \mathrm{~mL}^{-1}\right)$ and Lepadella patella $\left(17.8 \pm 52.8\right.$ ind. $\left.100 \mathrm{~mL}^{-1}\right)$ showed the highest densities. The other species presented densities of less 
Tab I. List of zooplankton recorded in bromeliad phytotelms and adhered to frog species in a Semideciduous Stationary Forest remnant, Pernambuco, Brazil. The asterisk represents the species that were recorded in Tapacurá reservoir by ALmEIDA et al. (2012). The second column stands for the mean density in ind. $100 \mathrm{~mL}^{-1}$ for species and eggs. $100 \mathrm{~mL}^{-1}$ for resting eggs [PR, Pristimantis ramagii (Boulenger, 1888); DD, Dendropsophus decipiens (Lutz, 1925); SP, Scinax pachycrus (Miranda-Ribeiro, 1937); SA, Scinax auratus (Wied-Neuwied, 1821); SX, Scinax x-signatus (Spix, 1824); n, number of individuals sampled by anuran species; FO, frequency of occurrence (\%)].

\begin{tabular}{|c|c|c|c|c|c|c|c|c|}
\hline \multirow[b]{2}{*}{ Taxa } & \multicolumn{2}{|c|}{ Phytotelm $(\mathrm{n}=19)$} & \multicolumn{6}{|c|}{ Anuran $(n=14)$} \\
\hline & Record & FO $(\%)$ & $\begin{array}{c}\text { PR } \\
(\mathrm{n}=8)\end{array}$ & $\begin{array}{c}\mathrm{DD} \\
(\mathrm{n}=2)\end{array}$ & $\begin{array}{c}\text { SP } \\
(\mathrm{n}=2)\end{array}$ & $\begin{array}{c}\text { SA } \\
(\mathrm{n}=1)\end{array}$ & $\begin{array}{c}\mathrm{SX} \\
(\mathrm{n}=3)\end{array}$ & $\mathrm{FO}(\%)$ \\
\hline \multicolumn{9}{|l|}{ Rotifera } \\
\hline Anuraeopsis fissa Gosse, 1851* & - & - & $\mathrm{x}$ & & & & & 5.3 \\
\hline Brachionus calyciflorus Pallas, $1766^{*}$ & $0.2 \pm 0.9$ & 5.3 & & & & $\mathrm{x}$ & $\mathrm{x}$ & 15.8 \\
\hline Brachionus havanaensis Rousselet, 1911* & $0.04 \pm 0.2$ & 5.3 & & & $\mathrm{x}$ & & & 5.3 \\
\hline Colurella uncinata (Müller, 1773) & $0.2 \pm 0.9$ & 5.3 & & & & & & - \\
\hline Filinia opoliensis (Zacharias, 1898) & $0.2 \pm 0.9$ & 10.5 & & & & & & - \\
\hline Keratella tropica (Apstein, 1907)* & $0.04 \pm 0.2$ & 5.3 & & & & $\mathrm{x}$ & & 5.3 \\
\hline Lecane bulla (Gosse, 1851)* & $0.04 \pm 0.2$ & 5.3 & & & & & & - \\
\hline Lecane closterocerca (Schmarda, 1859) & $\begin{array}{c}19.6 \pm \\
63.5\end{array}$ & 15.8 & & & & & & - \\
\hline Lecane nana (Murray, 1913) & $3.5 \pm 9.5$ & 21.1 & $\mathrm{x}$ & $\mathrm{x}$ & $\mathrm{x}$ & $\mathrm{x}$ & $\mathrm{x}$ & 47.4 \\
\hline Lecane pyriformis (Daday, 1905) & - & - & & & & & $\mathrm{x}$ & 5.3 \\
\hline Lecane subtilis Harring \& Myers, 1926 & $0.6 \pm 2.6$ & 5.3 & & & & $\mathrm{x}$ & & 5.3 \\
\hline Lecane sp. & $0.6 \pm 2.6$ & 5.3 & & & & & & - \\
\hline Lepadella patella (Müller, 1773)* & $\begin{array}{c}17.8 \pm \\
52.8\end{array}$ & 52.6 & $\mathrm{x}$ & & $\mathrm{x}$ & & & 10.5 \\
\hline Testudinella patina (Hermann, 1783) & - & - & & $\mathrm{x}$ & & $\mathrm{x}$ & & 5.3 \\
\hline Bdelloidea* & $\begin{array}{c}296.2 \pm \\
691.5\end{array}$ & 78.9 & $\mathrm{x}$ & & $\mathrm{x}$ & $\mathrm{x}$ & $\mathrm{x}$ & 26.3 \\
\hline \multicolumn{9}{|l|}{ Cladocera } \\
\hline Diaphanosoma spinulosum Herbest, 1966* & - & - & & & & $\mathrm{x}$ & & 10.5 \\
\hline Macrothrix elegans Sars, 1900 & $0.1 \pm 0.6$ & 5.3 & & & & & & - \\
\hline \multicolumn{9}{|l|}{ Copepoda } \\
\hline Eucyclops neumani (Pesta, 1927) & $2.2 \pm 9.5$ & 5.3 & & & & & & - \\
\hline Cyclopoida (others) & $3.1 \pm 6.9$ & 26.3 & & & & & & - \\
\hline Calanoida & $0.1 \pm 0.4$ & 5.3 & & & & & & - \\
\hline Nauplius & $5.4 \pm 14.2$ & 26.3 & & & & $\mathrm{x}$ & & 5.3 \\
\hline Dormant eggs & $\begin{array}{c}20.3 \pm \\
60.8\end{array}$ & 36.8 & $\mathrm{x}$ & & & $\mathrm{x}$ & $\mathrm{x}$ & 26.3 \\
\hline
\end{tabular}

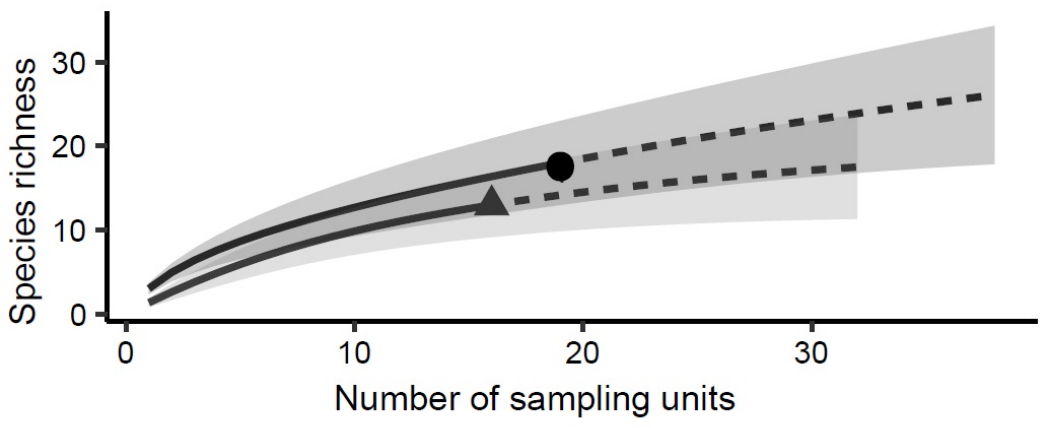

Fig. 2. Rarefaction curve considering zooplanktonic species frequency from both bromeliad tanks and frogs' skin in a Semideciduous Stationary Forest remnant, Pernambuco, Brazil. 
than 10 ind. $100 \mathrm{~mL}^{-1}$. On the other hand, the dormant eggs showed an average of $20.3 \pm 60.8$ eggs. $100 \mathrm{~mL}^{-1}$ (Tab. I).

Five species of frogs were recorded using the bromeliads: Pristimantis ramagii (Boulenger, 1888), Dendropsophus decipiens (Lutz, 1925), Scinax auratus (Wied-Neuwied, 1821) Scinax pachycrus (MirandaRibeiro, 1937) and Scinax x-signatus (Spix, 1824) (Tab. I). We collected 17 specimens, all of small size (SVL ranging from 2 to $5 \mathrm{~cm}$ ). All individuals from $S$. $x$-signatus were recorded only near bromeliads (soil and parts of other plants). Pristimantis ramagii and $D$. decipiens are species usually found on the ground in leaf-litter, and in low vegetation near waterbodies; in this study they were found between the bromeliad's leaves. These three species usually use the bromeliads only for foraging and shelter from predators. Scinax auratus and $S$. pachychrus are very adaptable species that live in lowland forest, usually in open habitats and rocky areas, often in bromeliads; all the specimens collected in this study were found within the phytotelm.

The zooplankton adhered to the body of frogs was represented by ten species, besides nauplius and Bdelloidea rotifers. The rotifers had the highest number of taxa (nine species). In addition, dormant eggs were also recorded (Tab. I). Overall, 70.59\% of registered frogs associated with bromeliads had zooplankton adhered to their bodies (12 specimens). Of these, $91.6 \%$ had active zooplankton forms and only $33.3 \%$ had dormant eggs.

The invertebrate composition was different between frogs' skin and in bromeliads' phytotelm tanks (Fig. 3; pseudo-F $=6.9, \mathrm{p}=0.003)$. When the percentage of similarity calculated by SIMPER were analyzed, we saw that the most common species shared between both treatments were Lecane nana which contributed with $14 \% \pm 13.7 \%$ of similarity, the morphotype of Bdelloidea (13.7\% $\pm 14.7 \%$ ) and Lepadella patella $(11.2 \% \pm 11.9 \%)$. Together, these species explain more than $50 \%$ of similarity among groups due to their higher frequency in each treatment.

The mean number of active zooplanktonic individuals found on frogs' skin was $2.76 \pm 3.61$ individuals per anuran, varying from zero on some specimens to maximum values of 14 on Scinax $x$-signatus. On the other hand, the number of resting forms was much lower, reaching no more than three dormant eggs on a specimen of Pristimantis ramagii. The general mean of resting eggs was $0.4 \pm 0.8$ eggs per anuran.

The rotifer Lecane nana was the invertebrate most often found on the body of the frogs $(47.4 \%)$, and it was registered on all the five frog species. The morphotype of the Bdelloidea class had the second highest frequency of occurrence in frogs $(23.5 \%)$, while cladocerans and copepods presented frequency of less than $11 \%$ (Tab. I). Five species were found exclusively attached to the frog's body, but were not registered in bromeliad phytotelms: the rotifers Anuraeopsis fissa Gosse, 1851, Lecane pyriformis (Daday, 1905), Testudinella patina (Hermann, 1783), and the cladoceran Diaphanosoma spinulosum Herbest, 1966. Among copepods, there were only juveniles. Moreover, $54.5 \%$ of all zooplankton species and dormant eggs were recorded adhered to the frogs (Tab. I). The frogs' body size does not explain the number of carried propagules (linear regression, $\left.\mathrm{R}^{2}=0.006, \mathrm{p}=0.72\right)$.

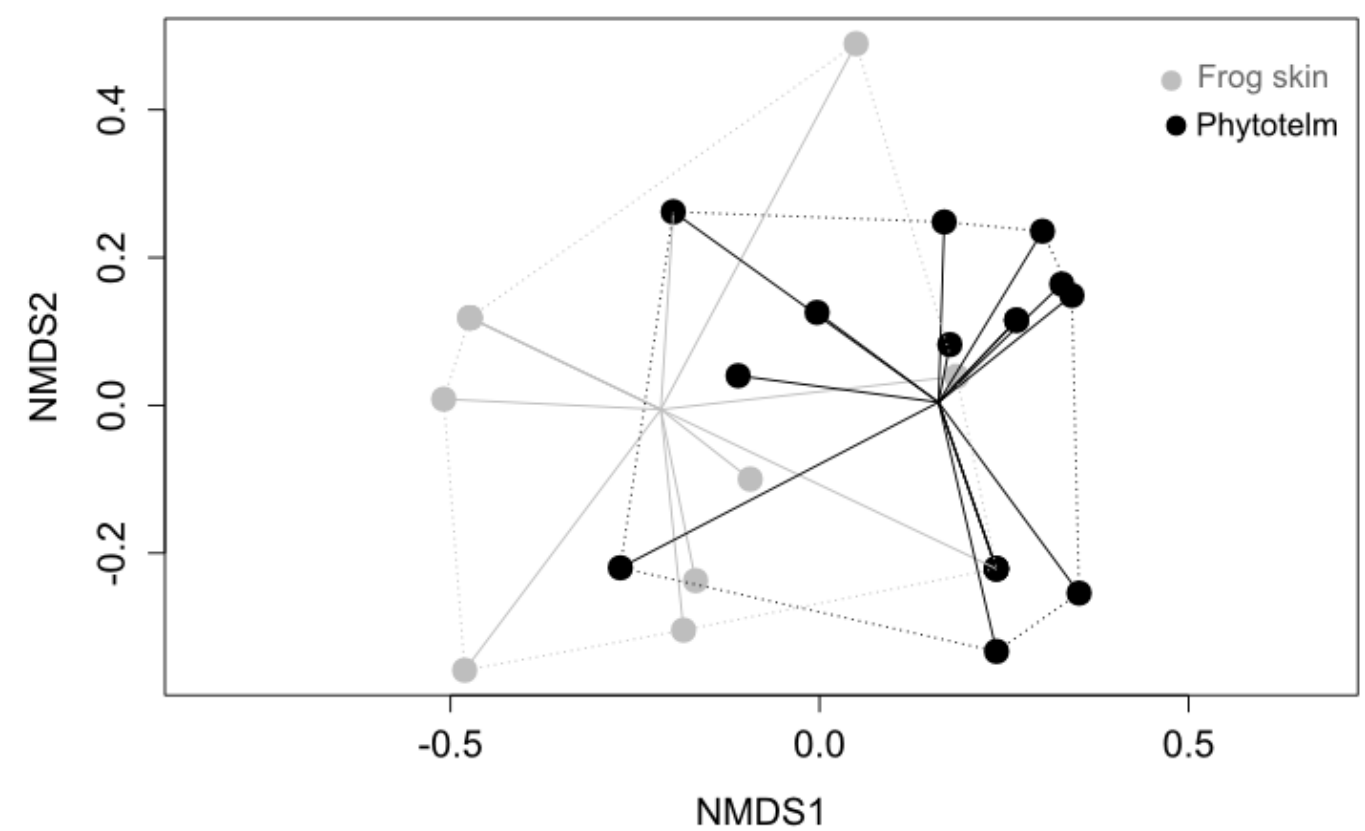

Fig. 3. Non-metric multidimensional scaling (NMDS) ordination of the zooplankton species showing differences in composition between frogs' skin (grey circles) and bromeliad phytotelms (black circles). Dashed lines indicate the range of each community dispersion and solid lines indicate the distance of each sample from centroid. 


\section{DISCUSSION}

Differently from what we expected, the zooplankton composition in bromeliads and on frog's skin was different and our hypothesis was refuted. Nevertheless, SIMPER analysis indicates that three rotifer species were strongly related between these treatments, and these three explain more than $50 \%$ of the similarity between bromeliads and frog's skin, which reinforces the evidence of dispersal. In addition, even though body size of frogs does not explain the number of propagules transported, the occurrence of active and dormant forms of zooplankton on their body brings strong evidence of the potential of these vertebrates to act as vectors of zooplankton among bromeliad tanks.

The richness on bromeliads was higher than that on frog's skin, which is expected, as a single vector cannot transport every species pool at once. Therefore, it was also evident that the richness of propagules on their skin tends to increase with increasing number of sampled frogs, possibly reaching the whole community. Rotifers, which cover most of the species recorded in this study, are known for their wide capacity for colonization among several habitats, from freshwater to estuarine and marine. According to SEGERS (2007), they are considered to have cosmopolitan distribution, occurring in different biogeographical regions. Despite this range of habitat occupation, these animals seem to depend on amphibians to colonize areas with bromeliads.

The rotifer genus Lecane is characterized by having many species that are commonly associated with substrate (GreEN, 1984, 2003) which is related to its periphytic habit and structures for fixing (DugGan, 2001). Nevertheless, the species Lecane closterocerca did not occur on frogs, which reveals that individuals are in low flux between microcosms. However, it has been discovered in high abundance in the phytotelms where it found suitable conditions and, therefore, was able to establish a population. Thus we believe that our sampling efforts were not enough to detect this species or even its dispersal mechanism. Lecane nana, on the other hand, was frequently found on anuran skin, and this pattern leads to its higher capacity to adhere and disperse. Since $L$. closterocerca was already well established in the phytotelm, L. nana apparently could not compete for resources and therefore remained less abundant within bromeliad tanks. As a matter of the fact, its high dispersal capacity may protect L. nana from competitive exclusion and extinction by means of rescue effect (KNeItel \& Miller, 2003; Perrin, 2009). In short, frog-mediated dispersal may play an important role in maintaining and regulating invertebrate populations.

The Bdelloidea class was the densest taxa in bromeliads and the second most frequent regarding frogs. This class is characterized by not producing dormant eggs, but its members are resistant to desiccation and starvation (RicCI \& FONTANETO, 2009). Therefore, they can resist longer periods adhered to the anuran body, until the frog visits a new phytotelm. On the other hand, the high moisture of the frog's body acts in preventing the dehydration of organisms during dispersal (LOPEZ et al., 2005).
Our study showed that the dispersal of active forms of zooplankton by anurans is more numerous and frequent than of dormant eggs. Possibly, these organisms can be easily dispersed, alive, by anuran skin in the same way as ostracods and annelids are (Lopez et al., 2005; SABAGH et al., 2011; SABAGH \& Rocha, 2014). Besides active forms, the occurrence of different types of dormant eggs in phytotelms and adhered to frogs reveals the capacity of these environments as sources of biodiversity in humid forests (Frank \& Lounibos, 1987). Thus, although they are less dispersed, the formation of dormant eggs for many zooplanktonic organisms is an important survival strategy, since it allows them to maintain populations in unstable habitats like phytotelms. Furthermore, either under optimal conditions for passive dispersal by wind, rain or adduced passively by other organisms, including macroinvertebrates and vertebrates (JENKINS \& UNDERWOOD, 1998), the resting stages are the ones that allow them to colonize other habitats.

All amphibians found had already been recorded in the location (SANTOS \& Moura, 2012). Because of their foraging habit in different habitats and the need to remain always in contact with some waterbody, e.g. bromeliads (HADDAD et al., 2013), bromelicolous frogs are configured as potential dispersers of aquatic microorganisms. Our study revealed the dissimilarity between the composition of zooplankton communities in both the phytotelm tanks and recovered from vectors' skin, which means that there are some other sources of propagules besides the bromeliads. Some zooplankton species were also found in the Tapacurá reservoir (ALMEIDA et al., 2012), which is the nearest studied waterbody; however, the chemical features of water induced by the bromeliads themselves can constitute a barrier for some species (LOPEZ et al., 2009), and only $2 \%$ of fauna associated with bromeliads are occasional (ARMBRUSTER $e t$ al., 2002). Thus, even though frogs bring propagules from other waterbodies, the bromeliad's features will select which species are able to survive.

The number of propagules carried by frogs is not related to their body size, which excludes our second hypothesis about body area and probability of adhesion (see Harvey et al., 1983; Ulrich \& Gotelli, 2007). Other variables may better explain this interaction, such as exposure time of frogs to invertebrates, density of vertebrates in bromeliads, sex behavior, and type of vector. Thus, the longer the frog passes within phytotelm water, for example, the greater the probability of invertebrates sticking on it. In addition, we also highlight the influence of resource availability, since there is the possibility that zooplankton is seeking food on the frog's skin. Some studies show that frogs have a parasitic fungus on their body, which may serve as a potential food source for zooplanktonic organisms (MeNDelson et al., 2006; BucK et al., 2011).

We conclude that the anurans are potentially dispersers, by phoresy, of rotifers, cladocerans and copepods between phytotelms, particularly among bromeliads and probably other waterbodies. Moreover, they generally disperse the active forms of these invertebrates more frequently than 
dormant forms. In addition, the frog's body size has no influence on the number of propagules carried.

Acknowledgments. We thank the Universidade Federal Rural de Pernambuco (UFRPE), for the financial and logistic support for this research. We are also grateful to the researchers A. C. A. El-Deir and W. R. Telino-Júnior as well as the journal reviewers for the helpful suggestions and insights from the experimental design of this study until the final text. Research was conducted under SISBIO-ICMBio permits ( $\left.\mathrm{N}^{\circ} 53223-2\right)$. All work was conducted in accordance with the Animal Ethics Committee of the Universidade Federal Rural de Pernambuco (permit number 058/2015).

\section{REFERENCES}

Almeida, V. L. S.; LarrazÁBal, M. E. L.; Moura, A. N. \& Melo-JúNior, M. 2012. Zooplâncton do reservatório de Tapacurá (PE, Brasil): influência do habitat e do estado trófico sobre a biodiversidade. In: Moura, G. J. B.; Azevedo-Junior, S. M. \& El-Deir, A. C. A. eds. A biodiversidade da estação ecológica do Tapacurá: uma proposta de manejo e conservação. Recife, NUPEEA, p. 99-127.

Alvares, C. A.; Stape, J. L.; Sentelhas, P. C.; Gonçalves, J. L. M. \& SPAROveK, G. 2013. Köppen's climate classification map for Brazil. Meteorologische Zeitschrift 22(6):711-728.

Anderson, M. J. \& Walsh, D. C. I. 2013. Permanova, Anosim, and the Mantel test in the face of heterogeneous dispersions: What null hypothesis are you testing? Ecological monographs 83(4):557-574.

Andrade, E. V. E.; Palhas, J. L. \& Moura, G. J. B. 2013. Diurnal habitat segregation by tadpoles in two temporary ponds in an Atlantic Rainforest remnant, Northeastern Brazil. Hydrobiology 715(1):1-14.

Armbruster, P.; Hutchinson, R. A. \& Cotgreave, P. 2002. Factors influencing community structure in a South American tank bromeliad fauna. Oikos 96(2):225-234

Benzing, D. H. 2000. Bromeliaceae: Profile of an adaptive radiation. Cambridge, Cambridge University Press. 690p.

BohonaK, A. J. \& Jenkins, D. G. 2003. Ecological and evolutionary significance of dispersal by freshwater invertebrates. Ecology Letters 6(8):783-796.

Buck, J. C.; Truong, L. \& Blaustein, A. R. 2011. Predation by zooplankton on Batrachochytrium dendrobatidis: Biological control of the deadly amphibian chytrid fungus?. Biodiversity and Conservation 20(14):3549-3553.

Cohen, G. M. \& Shurin, J. B. 2003. Scale-dependence and mechanisms of dispersal in freshwater zooplankton. Oikos 103(3):603-617.

Colombo, A. F. \& Joly, C. A. 2010. Brazilian Atlantic Forest lato sensu: the most ancient Brazilian forest, and a biodiversity hotspot, is highly threatened by climate change. Brazilian Journal of Biology 70(3):697708.

Duarte, C. C.; Galvíncio, J. D.; De Barros Corrêa, A. C. \& Araújo, M. D. S. B. 2007. Análise fisiográfica da bacia hidrográfica do Rio Tapacurá-PE. Revista de Geografia 24(2):50-64.

DugGan, I. C. 2001. The ecology of periphytic rotifers. Hydrobiologia 446(447):139-148.

ElmOOR-LouREIRO, L. M. A. 1997. Manual de Identificação de Cladóceros Límnicos do Brasil. Brasília, Universo. 156p.

FERREIRA, I. N. \& CAVALCANTI, L. H. 2010. Disponibilidade de microhabitats para Myxomycetes em Floresta Atlântica: Bromeliaceae. Biotemas 23(3):1-10.

Frank, J. H. \& Lounibos, L. P. 1987. Phytotelmata: Swamps or Islands? The Florida Entomologist 70(1):14-20.

GREEN, J. 1984. Zooplankton associations in the swamps of southern Sudan. Hydrobiologia 113(1):93-98.

Green, J. 2003. Associations of planktonic and periphytic rotifers in a tropical swamp, the Okavango Delta, Southern Africa. Hydrobiologia 490(1-3):197-209.

Haddad, C. F. B.; Toledo, L. F.; Prado, C. P. A.; Loebmann, D.; Gasparini, J. L. \& SAzima, I. 2013. Guia de anfíbios da Mata Atlântica: diversidade de biologia. São Paulo, Anolisbooks. 544p.

Harvey, P. H.; Colwell, R. K.; Silvertown, J. W. \& May, R. M. 1983. Null models in ecology. Annual Review of Ecology and Systematics 14(1):189-211.
Hsien, T. C.; MA, K. H. \& CHAO, A., 2016. iNEXT: an R package for rarefaction and extrapolation of species diversity (Hill numbers). Methods in Ecology and Evolution 7(12):1451-1456.

Islair, P.; Carvalho, K. S.; Ferreira, F. C. \& Zina, J. 2015. Bromeliads in Caatinga: an oasis for invertebrates. Biotemas 28(1):67-77.

JENKINS, D. G. \& UNDERWOOD, M. O. 1998. Zooplankton may not disperse readily in wind, rain, or waterfowl. Hydrobiologia 387(388):15-21.

Kneitel, J. M. M. \& Miller, T. E. E. 2003. Dispersal rates affect species composition in metacommunities of Sarracenia purpurea inquilines. The American Naturalist 162(2):165-171.

Koste, W. 1978. Rotatoria die Rädertiere Mitteleuropas bergründet von Max Voigt. Monogononta. Berlin, Gebrüder Borntraeger. v.2, p.1-234.

LANGENHEDER, S. \& RAGNARSSON, H. 2007. The role of environmental and spatial factors for the composition of aquatic bacterial communities. Ecology 88(9):2154-2161.

LitTLE, T. \& Hebert, P. 1996. Endemism and ecological islands: the ostracods from Jamaican bromeliads. Freshwater Biology 36(2):327-338.

Lopez, L. C. S.; Alves, R. R. N. \& Rios, R. I. 2009. Micro-environmental factors and the endemism of bromeliad aquatic fauna. Hydrobiologia 625(1): 151-156.

Lopez, L. C. S.; Filizola, B.; Deiss, I. \& Rios, R. I. 2005. Phoretic behaviour of bromeliad annelids (Dero) and ostracods (Elpidium) using frogs and lizards as dispersal vectors. Hydrobiologia 549(1):15-22.

Lopez, L. C. S.; Rodrigues P. J. \& Rios, R. I. 1999. Frogs and snakes as phoretic dispersal agents of bromeliad ostracods (Limnocytheridae: Elpidium) and annelids (Naididae: Dero). Biotropica 31(4):705-708.

Mageski, M.; Coutinho, H. \& Clemente-CARVAlHo, R. 2014. Distribuição espacial e seleção de hábitat por anfíbios anuros em Mata Atlântica sobre a formação Barreiras no sudeste do Brasil. Natureza Online 12:230-234.

Matsumura-Tundisi, T. 1986. Latitudinal distribution of Calanoida copepods in freshwater aquatic systems of Brazil. Revista Brasileira de Biologia 46(3):527-553.

Mendelson, M. J. R.; Lips, K. R.; Gagliardo, R. W.; RabB, G. B.; Collins, J. P.; Diffendorfer, J. E.; DaszaK, P.; Ibanez, D. R.; ZipPel, K. C.; Lawson, D. P.; Wright, K. M.; Stuart, S. N.; Gascon, C.; Da Silva, H. R.; Burrowes, P. A.; Joglar, R. L.; La Marca, E.; Lotters, S.; Du Preez, L. H.; Weldon, C.; Hyatt, A.; Rodriguez-Mahecha, J. V.; Hunt, S.; Robertson, H.; Lock, B.; Raxworthy, C. J.; Frost, D. R.; Lacy, R. C.; Alford, R. A.; Campbell, J. A.; Parra-Olea, G.; Bolanos, F.; Domingo, J. J. C.; Halliday, T.; Murphy, J. B.; Wake, M. H.; Coloma, L. A.; Kuzmin, S. L.; Price, M. S.; Howell, K. M.; Lau, M.; Pethiyadora, R.; Boone, M.; Lannoo, M. J.; Blaustein, A. R.; Dobson, A.; Griffiths, R. A. L.; Crump, M.; Wake, D. B. \& BRODIE JR, E. D. 2006. Biodiversity - Confronting amphibian declines and extinctions. Science 313:48.

Mouquet, N. \& Loreau, M. 2003. Community Patterns in Source-Sink Metacommunities. The American Naturalist 162(5):544-557.

NGai, J. T. \& SRIVASTAVA, D. S. 2006. Predators accelerate nutrient cycling in a bromeliad ecosystem. Science 314(5801):963-963.

Oksanen, J.; Blanchet, F. G.; Kindt, R.; Legendre, P.; Minchin, P. R. \& O'Hara, R. B. 2017. Vegan: Community Ecology Package. R package version 2.4-3. Available at $<$ https://cran.r-project.org/web/ packages/vegan/index.html>. Accessed on 20 October 2018.

Peixoto, O. L. 1995. Associação de anuros a bromeliáceas na Mata Atlântica Revista da Universidade Federal Rural do Rio de Janeiro. Série Ciências da Vida 17(2):75-83.

Perrin, N. 2009. Dispersal In: Levin, S. A. ed. The Princeton guide to ecology. Princeton, University Press, p.45-50.

R Core Team. 2018. R: A language and environment for statistical computing. R Foundation for Statistical Computing, Vienna, Austria. Available at: $<$ https://www.R-project.org/ $>$ Accessed on: 20 October 2018.

REID, J. W. 1985. Chave de identificação e lista de referências bibliográficas para espécies continentais sul-americanas de vida livre da ordem Cyclopoida (Crustacea, Copepoda). Boletim de Zoologia 9(9):17-143.

Ricci, C. \& Fontaneto, D. 2009. The importance of being a bdelloid: Ecological and evolutionary consequences of dormancy. Italian Journal of Zoology 76(3):240-249.

Sabagh, L. T. \& Rocha, C. F. D. 2014. Bromeliad treefrogs as phoretic hosts of ostracods. Naturwissenschaften 101(6):493-497. 
Sabagh, L. T.; Dias, R. J. P.; Branco, C. W. C. \& Rocha, C. F. D. 2011. News records of phoresy and hyperphoresy among treefrogs, ostracods, and ciliates in bromeliad of Atlantic forest. Biodiversity and Conservation 20(8): 1837-1841.

Sabagh, L. T.; Ferreira, G. L.; Branco, C. W. C.; Rocha, C. F. D. \& Dias, N. Y. N. 2012. Larval Diet in Bromeliad Pools: A Case Study of Tadpoles of Two Species in the Genus Scinax (Hylidae). Copeia 2102(4):683-689.

Santos, E. M. \& Moura, G. J. B. 2012. Os Anfíbios da Estação Ecológica do Tapacurá. In: Moura, G. J. B.; Azevedo-Júnior, S. M. \& ElDeIr, A. C. A. eds. A Biodiversidade da Estação Ecológica do
Tapacurá - Uma Proposta de Manejo e Conservação. Recife, NUPEEA, p. 213-268.

Schmeller, D. S.; Blooi, M.; Martel, A.; Garner, T. W. J.; Fisher, M. C.; Azemar, F.; Clare, F. C.; Leclerc, C.; JäGer, L.; Guevara-Nieto, M.; Loyau, A. \& Pasmans, F. 2014. Microscopic aquatic predators strongly affect infection dynamics of a globally emerged pathogen. Current Biology 24(2): 176-180.

Segers, H. 2007. Annotated cheklist of the rotifers (Phylum Rotifera), with notes on nomenclatures, taxonomy and distribution. Zootaxa 1564:1-104.

ULRICH, W. \& GOTELLI, N. J. 2007. Null model analysis of species nestedness patterns. Ecology 88(7):1824-1831. 